TECHNICAL TRANSACTIONS 8/2018

MECHANICS

DOI: $10.4467 / 2353737$ XCT.18.124.8899 SUBMISSION OF THE FINAL VERSION: 3/08/2018

\author{
Łukasz Ślusarczyk (iD) orcid.org/0000-0002-3565-7868 \\ slusarczyk@mech.pk.edu.pl \\ Emilia Franczyk \\ Institute of Production Engineering, Faculty of Mechanical Engineering, Cracow \\ University of Technology
}

\title{
EXPERIMENTAL DETERMINATION OF FORCES IN A CUTTING ZONE DURGING TURNING A STAINLESS STEEL SHAFT
}

EKSPERYMENTALNE WYZNACZANIE SIŁ W STREFIE SKRAWANIA PODCZAS

TOCZENIU WAEKA ZE STALI NIERDZEWNEJ

\begin{abstract}
The article presents the results of laboratory tests, the aim of which was to measure cutting forces during parallel turning of an AMS 5643 steel bar. The cutting trials were registered with a 3-axis Kisler 9257B piezoelectric dynamometer, and the DynoWare computer program was used to archive and analyse the results. The experimental test plan for variable cutting parameters $\left(v_{c}, a_{\beta} f\right)$ was created according to the Taguchi method and the statistical analysis of the results was performed using ANOVA. The work involved carrying out 9 tests with the use of an uncoated carbide cutting insert. The obtained test results will be used to specify a simulation model of the cutting process.

Keywords: stainless steel, cutting forces, ANOVA
\end{abstract}

\section{Streszczenie}

Artykuł prezentuje wyniki badań laboratoryjnych pomiaru sił skrawania podczas toczenia wzdłużnego wałka ze stali AMS 5643. Próby skrawne rejestrowano 3-osiowym siłomierzem piezoelektrycznym Kisler 9257B, do archiwizacji i analizy wyników pomiarów zastosowano program komputerowy DynoWare. Eksperymentalny plan badań dla zmiennych parametrów skrawania $\left(v_{\nu}, a_{\beta} f\right)$ stworzono według metody Taguchi, a statystyczne opracowanie wyników wykonano za pomocą analizy ANOVA. W ramach prac zostało przeprowadzone 9 testów z zastosowaniem plytki skrwającej weglikowej niepokrywanej. Uzyskane wyniki badań będą wykorzystane do uściślenia modelu symulacyjnego procesu skrawania.

Słowa kluczowe: stal nierdzewna, siły skrawania, ANOVA 


\section{Introduction}

Chip machining is one of the most common ways of shaping parts of machines and devices. The use of modern tools and numerically controlled machines enables obtaining objects of high technological quality [5]. The dynamic development of the aviation and automotive industries forces the use of machining in the production of complex components, often made from special, difficult-to-cut materials. At the stage of production planning, the correct selection of cutting parameters is very important for the issue [2, 3]. For this purpose, simulation methods are used, and laboratory tests are carried out. There are many computer programs available on the market that allow simulations of the phenomena that occur during the cutting process, including the determination of cutting forces or temperature values in the cutting zone. Simulation results should be verified with the results of laboratory tests. This is important when calibrating the simulation models of the cutting process $[7,8]$. In the literature, a lot of space concerns improving the efficiency of the cutting process, while maintaining a minimal wear of the cutting tools $[1,4]$. One of the practical ways to accomplish this task is to monitor and reduce cutting forces [6]. During rough machining, process efficiency is more important than a reduction of the cutting forces, and therefore great cutting depths, high feed rates and relatively low cutting speeds are assumed. When finishing, the cutting forces affecting the accuracy of the workpiece should be as low as possible. In this case, small cutting depths and feeds as well as higher cutting speeds are used. Many different conditions affect the cutting forces. These include, among other things, the geometry of the cutting tool's edge as well as the type and properties of the material being processed.

\section{Conducted research}

The laboratory stand was equipped with a set of measuring instruments to record the cutting forces of components. The arrangement of measuring instruments is shown in Fig. 1.
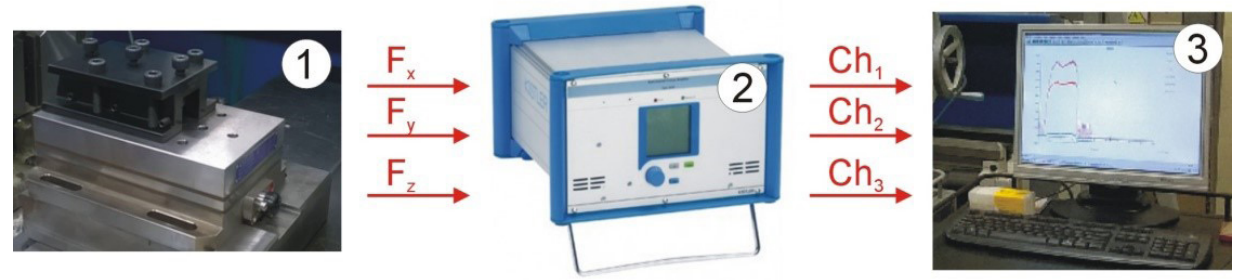

Fig. 1. The arrangement of measuring instruments to record the cutting forces of components:

1. KISTLER 9257B 3 axis piezoelectric dynamometer,

2. KISTLER type 5070A charge amplifier,

3. PC with DynoWare software.

The cutting force recording frequency was $1000 \mathrm{~Hz}$. The combined measuring path enabled measurements of the components of the total cutting force with inaccuracy $F_{x}$ - feed force 
and $F_{y}$ - radial force: $\pm 0,25 \mathrm{~N}, F_{z}-$ tangential force: $\pm 1 \mathrm{~N}$. Fig. 2 presents the dynamometer mounted on the lathe slide and the tool in the holder. 1 - piezoelectric dynamometer, 2 single-position tool holder with insert installed, 3 - workpiece: AMS 5643 steel shaft.

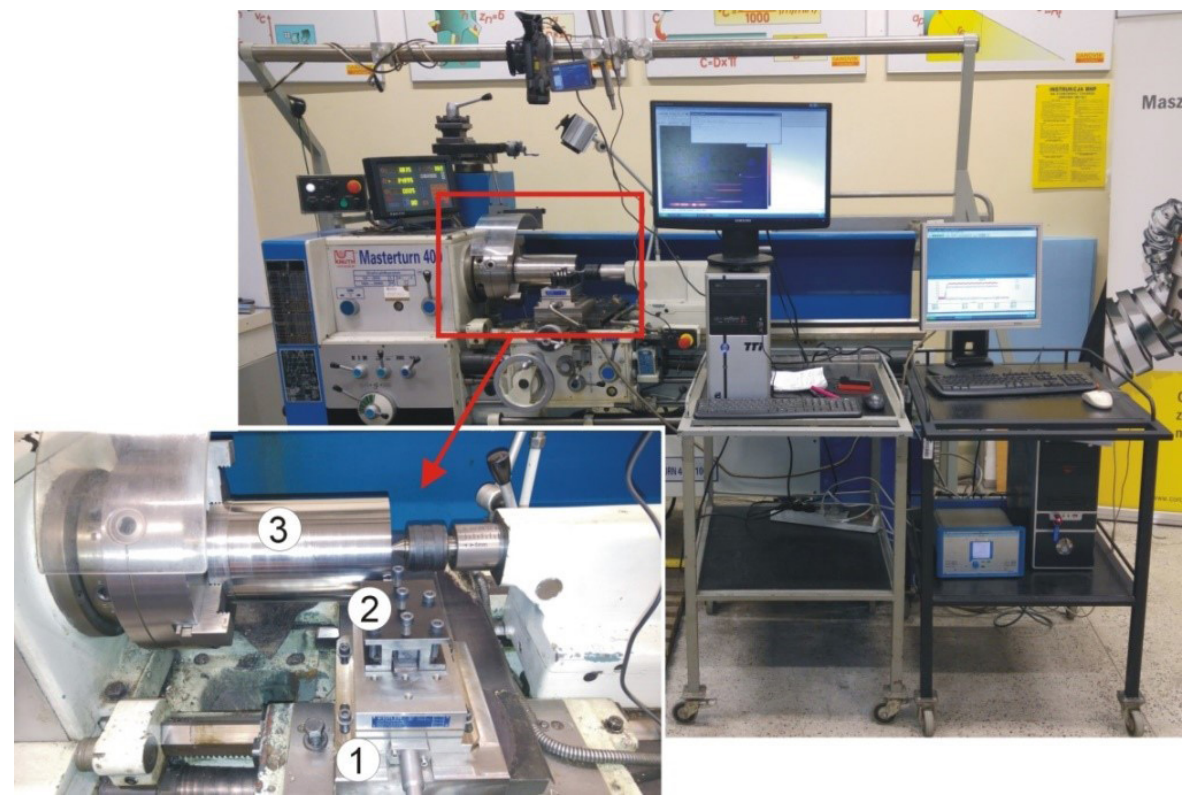

Fig. 2. The dynamometer mounted on the lathe slide and the tool in the holder

The machined material was an AMS 5643 stainless steel bar. This material belongs to the group of low-carbon, precipitation-hardened stainless steels. It is characterised by high static and fatigue strength, resistance to corrosion and high operating temperatures. The chemical composition of the steel according to the standards [10] is presented in Table 1.

Table 1. Chemical composition of AMS 5643 steel [9]

\begin{tabular}{|c|c|c|}
\hline & Min. [\%] & Max. [\%] \\
\hline $\mathrm{C}$ & - & 0.07 \\
\hline $\mathrm{Si}$ & - & 0.07 \\
\hline $\mathrm{Mn}$ & - & 1.50 \\
\hline $\mathrm{P}$ & - & 0.04 \\
\hline $\mathrm{S}$ & - & 0.015 \\
\hline $\mathrm{Cr}$ & 15.00 & 17.00 \\
\hline $\mathrm{Mo}$ & - & 0.60 \\
\hline $\mathrm{Ni}$ & 3.00 & 5.00 \\
\hline $\mathrm{Cu}$ & 3.00 & 5.00 \\
\hline
\end{tabular}

A triangular insert, without a protective coating, made of S20 sintered carbide was used for parallel turning test runs. The insert was mounted in the holder, and the wedge angle was $-6^{\circ}$. The geometrical parameters of the cutting insert used are presented in Table 2. 
Table 2. Geometrical parameters of the cutting insert used

\begin{tabular}{|c|c|c|c|}
\hline Name & Picture & Holder & $\begin{array}{c}\text { Insert geometry in } \\
\text { the tool coordinate } \\
\text { system }\end{array}$ \\
\hline & & & \\
& & & \\
& & PTGNR & $\alpha=5^{\circ}$ \\
& & \\
Uncoated plate & & \\
with chip flute & & 2020K16 & \\
& & & \\
& & & \\
\hline
\end{tabular}

\section{Findings}

The test plan for the influence of three independent factors $\left(v_{c} f\right.$ and $\left.a_{p}\right)$ on the total cutting force value was developed in accordance with the experimental design guidelines (DOE). A research plan was generated using the Taguchi method. Parameters $v_{c} f$ and $a_{p}$ were assumed respectively as independent variables A, B and C. Ranges of the variation of cutting parameters were determined on the basis of catalogue data. Table 3 presents assumed values of the cutting parameters.

Table 3. Values of cutting parameters

\begin{tabular}{|c|c|c|c|c|}
\hline Symbol & Cutting parameters & \multicolumn{3}{|c|}{ Parameter values } \\
\hline A & $v_{c}[\mathrm{~m} / \mathrm{min}]$ & 90 & 120 & 150 \\
\hline B & $f[\mathrm{~mm} / \mathrm{rev}]$ & 0.105 & 0.153 & 0.211 \\
\hline C & $a_{p}[\mathrm{~mm}]$ & 0.5 & 1 & 1.5 \\
\hline
\end{tabular}

A research plan generated according to the Taguchi method is shown in Table 4. The research plan was compiled in the form of an orthogonal table L9, which describes the individual trials for three factors at their different values (levels).

Table 4. Research plan by the Taguchi method

\begin{tabular}{|c|c|c|c|c|c|c|}
\hline \multirow{2}{*}{ Sample number } & \multicolumn{3}{|c|}{ Parameters } & \multicolumn{3}{c|}{ Parameter values } \\
\cline { 2 - 7 } & A & B & C & $v_{c}[\mathbf{m} / \mathbf{m i n}]$ & $f[\mathbf{m m} / \mathbf{r e v}]$ & $a_{p}[\mathbf{m m}]$ \\
\hline 1 & 1 & 1 & 1 & 90 & 0.105 & 0.5 \\
\hline 2 & 1 & 2 & 2 & 90 & 0.153 & 1.0 \\
\hline 3 & 1 & 3 & 3 & 90 & 0.211 & 1.5 \\
\hline 4 & 2 & 1 & 2 & 120 & 0.105 & 1.0 \\
\hline
\end{tabular}




\begin{tabular}{|c|c|c|c|c|c|c|}
\hline \multirow{2}{*}{ Sample number } & \multicolumn{3}{|c|}{ Parameters } & \multicolumn{3}{c|}{ Parameter values } \\
\cline { 2 - 7 } & A & B & C & $v_{c}[\mathbf{m} / \mathbf{m i n}]$ & $f[\mathrm{~mm} / \mathbf{r e v}]$ & $a_{p}[\mathrm{~mm}]$ \\
\hline 5 & 2 & 2 & 3 & 120 & 0.153 & 1.5 \\
\hline 6 & 2 & 3 & 1 & 120 & 0.211 & 0.5 \\
\hline 7 & 3 & 1 & 3 & 150 & 0.105 & 1.5 \\
\hline 8 & 3 & 2 & 1 & 150 & 0.153 & 0.5 \\
\hline 9 & 3 & 3 & 2 & 150 & 0.211 & 1.0 \\
\hline
\end{tabular}

At the stage of statistical analysis of the results, the $S / N$ ratio was determined; the smaller the better criterion was adopted. According to Taguchi, this type of coefficient is used when it is appropriate to minimise some of the undesirable features of the product.

The $\mathrm{S} / \mathrm{N}$ ratio was calculated from the formula:

$$
\frac{S}{N}=-10 \cdot \log \left(\frac{1}{n} \sum_{i=1}^{n} y_{i}^{2}\right)
$$

On the basis of the conducted research, it was found that it is possible to determine the order of influence of particular factors $\left(v_{c}, f\right.$ and $\left.a_{p}\right)$ on the studied phenomenon. Table 5 presents the results of the analysis of the order of impact of parameters on the value of the total cutting force.

Table 5. Analysis of the order of factors influence on the value of the total cutting force

\begin{tabular}{|c|c|c|c|c|c|}
\hline Level & $\mathbf{F}=\mathbf{f}\left(v_{c}\right)$ & Level & $\mathbf{F}=\mathbf{f}(f)$ & Level & $\mathbf{F}=\mathbf{f}\left(a_{p}\right)$ \\
\hline 1 & 593.2 & 1 & 4456 & 1 & 343.9 \\
\hline 2 & 545.9 & 2 & 560.6 & 2 & 575.7 \\
\hline 3 & 555.2 & 3 & 688.1 & 3 & 774.7 \\
\hline Delta & 47.3 & & 242.6 & & 430.7 \\
\hline Rank & III & & II & & I \\
\hline
\end{tabular}

By analysing the results from table 5 , it can be concluded that the cutting force $a_{p}$ has the greatest influence on the cutting force value, flowed by the feed $f$, and the cutting speed $v_{c}$.

An exemplary cutting force value waveform for run no. 5 is presented in Fig. 3.

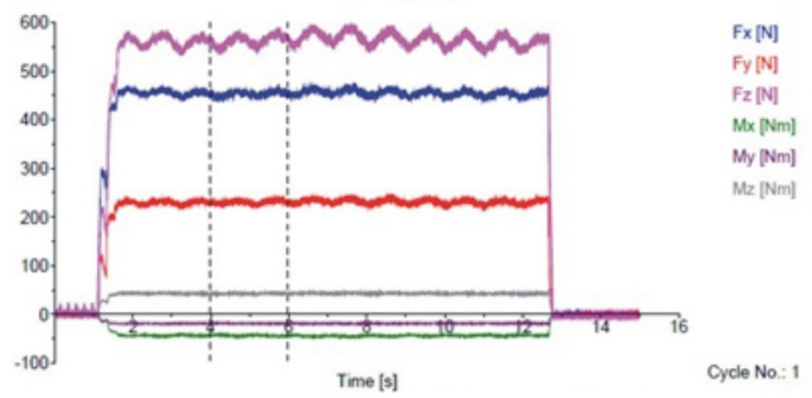

Fig. 3. An exemplary cutting force value waveform for run no. 5 
The components of the cutting force: the feed force, the radial force and the tangential cutting force from Fig. 3 are marked respectively as $F_{x}, F_{y}, F_{z}$. For further analysis based on the stabilised waveforms, the mean values of the cutting force components were measured, and the value of the total cutting force was determined. In addition, as part of the work, an ANOVA was carried out, on the basis of which a regression equation was obtained for the calculation of the total cutting force Fcalc.

$$
\begin{gathered}
F_{\text {calc }}\left(v_{c}, f, a_{p}\right)=548,8-8,10 \cdot v_{c}-3961,0 \cdot f+884,90 \cdot a_{p}+0,03 \cdot v_{c}^{2}+9200,0 \\
\cdot f^{2}+16,0 \cdot a_{p}^{2}+23,42 \cdot v_{c} \cdot f-3,75 \cdot v_{c} \cdot a_{p}
\end{gathered}
$$

The value of the correlation coefficient for the obtained equation is: $\mathrm{R}-\mathrm{Sq}=92.24 \%$, $\mathrm{R}-\mathrm{Sq}(\mathrm{adj})=84.24 \%$. The dependence of the calculated total cutting force on the cutting speed, feed rate and depth of cut is shown in the Fig. 4.

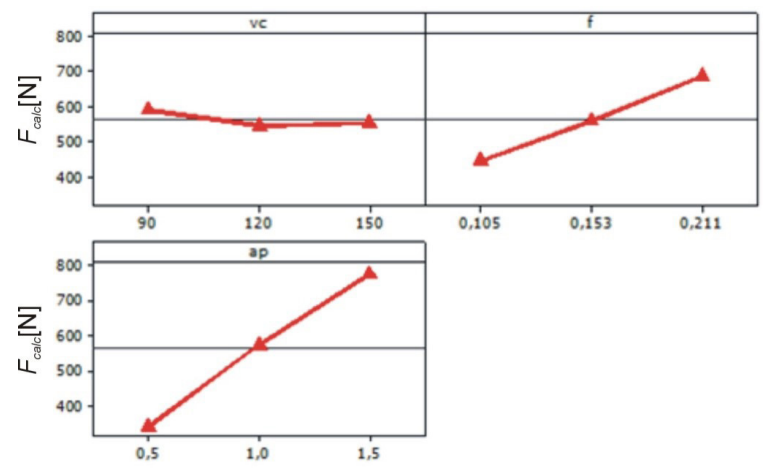

Fig. 4. The dependence of the calculate total cutting force on the cutting speed, feed rate and depth of cut

The measured values of the cutting force components $F_{x^{\prime}}, F_{y^{\prime}} F_{z^{\prime}}$ the total cutting force value $F, S / N$ ratio and the total cutting force value, calculated from the obtained regression equation Fcalc, are shown in Table 6.

Table 6. Experimental and calculated values of forces and $\mathrm{S} / \mathrm{N}$ ratio

\begin{tabular}{|c|c|c|c|c|c|c|}
\hline Run number & $F_{x}[\mathbf{N}]$ & $F_{y}[\mathbf{N}]$ & $F_{z}[\mathbf{N}]$ & $F[N]$ & $S / N[\mathrm{~dB}]$ & $F_{\text {calc }}[\mathbf{N}]$ \\
\hline 1 & 123.25 & 146.94 & 174.46 & 259.26 & -48.27 & 247.34 \\
\hline 2 & 324.93 & 218.74 & 414.01 & 569.94 & -55.12 & 558.02 \\
\hline 3 & 511.32 & 275.00 & 752.44 & 950.39 & -59.56 & 938.47 \\
\hline 4 & 286.33 & 183.46 & 312.01 & 461.51 & -53.28 & 440.32 \\
\hline 5 & 452.84 & 230.38 & 562.05 & 757.65 & -57.59 & 736.47 \\
\hline 6 & 178.45 & 254.13 & 280.43 & 418.41 & -52.43 & 397.07 \\
\hline 7 & 398.93 & 192.95 & 427.76 & 615.92 & -55.79 & 582.79 \\
\hline 8 & 168.78 & 215.88 & 224.34 & 354.15 & -50.98 & 320.82 \\
\hline 9 & 371.48 & 280.61 & 516.81 & 696.58 & -56.85 & 662.27 \\
\hline
\end{tabular}


Exemplary characteristics of the impact of individual cutting parameter on the total cutting force values are shown in the following graphs. Fig. $4 a, 4 b, 4 c$ present the influence of the cutting speed on the total cutting force value (at fixed a feed rate and depth of cut).

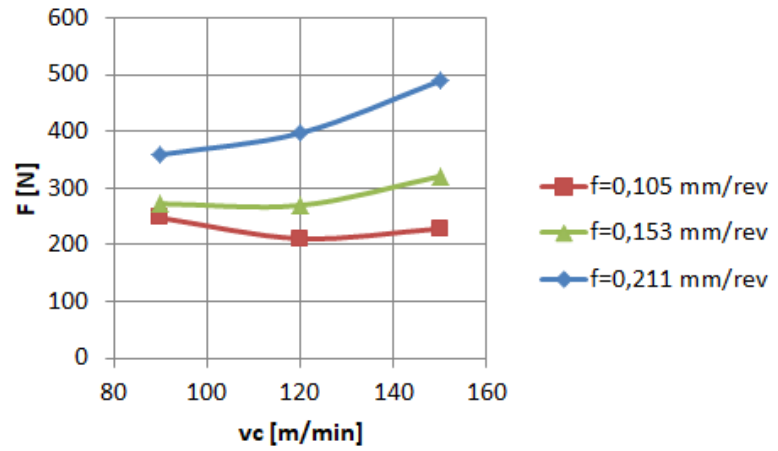

Fig. 4a. The influence of the cutting speed on the total cutting force, $a_{p}=0.5 \mathrm{~mm}$

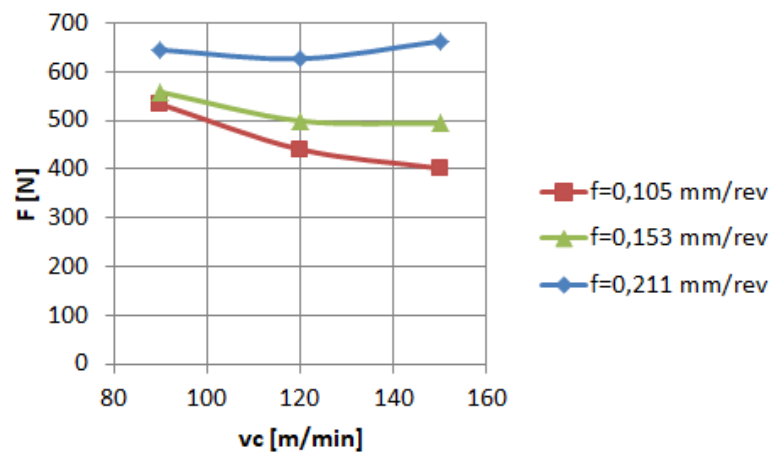

Fig. $4 \mathrm{~b}$. The influence of the cutting speed on the total cutting force, $a_{p}=1.0 \mathrm{~mm}$

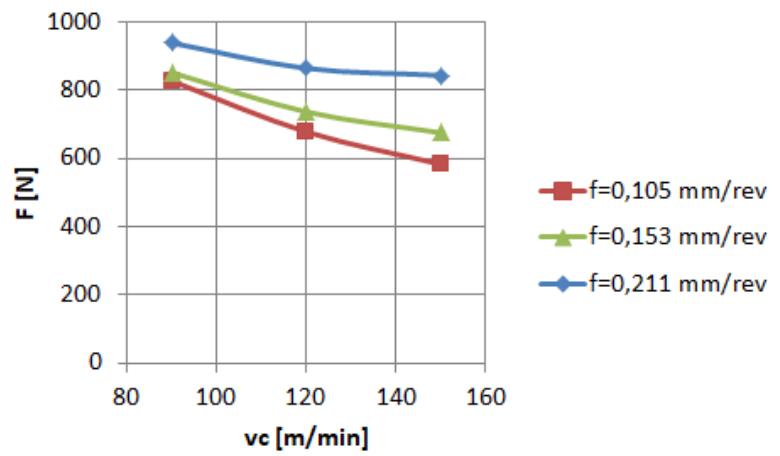

Fig. $4 \mathrm{c}$. The influence of the cutting speed on the total cutting force, $a_{p}=1.5 \mathrm{~mm}$ 
Fig. $5 a, 5 b, 5 c$ present the influence of the feed rate on the total cutting force value (at a constant cutting speed and depth of cut).

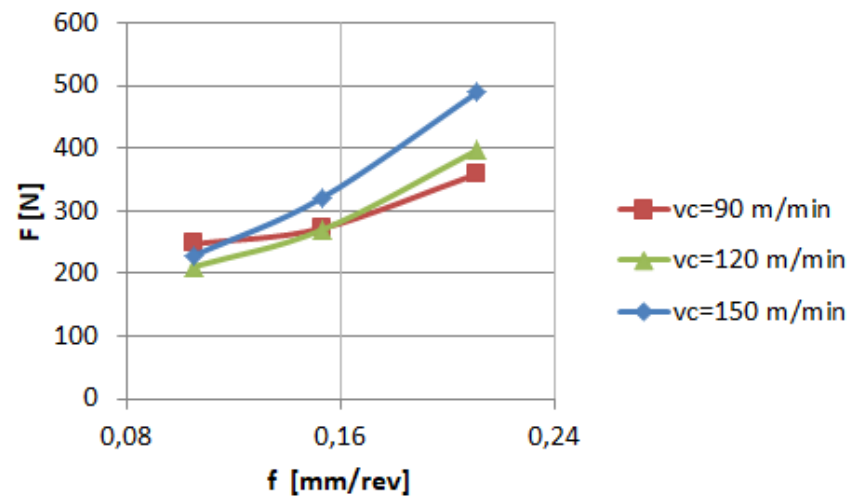

Fig. 5a. The influence of the feed rate on the total cutting force, $a_{p}=0.5 \mathrm{~mm}$

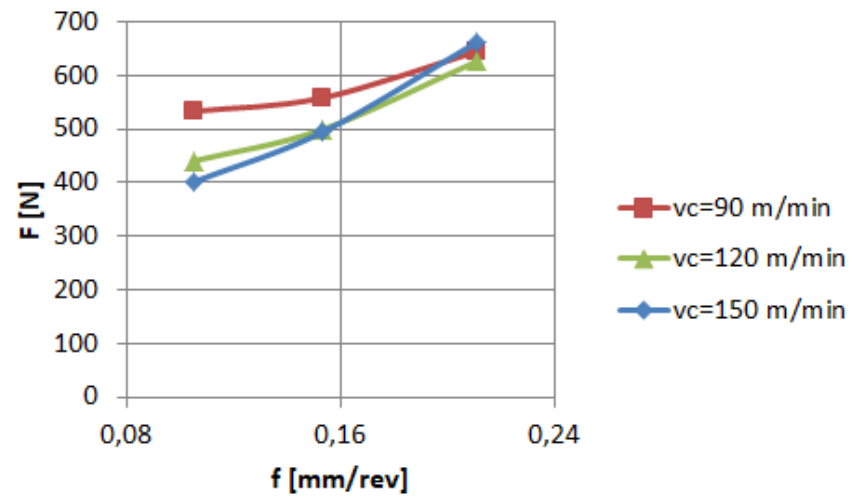

Fig. $5 \mathrm{~b}$. The influence of the feed rate on the total cutting force, $a_{p}=1,0 \mathrm{~mm}$

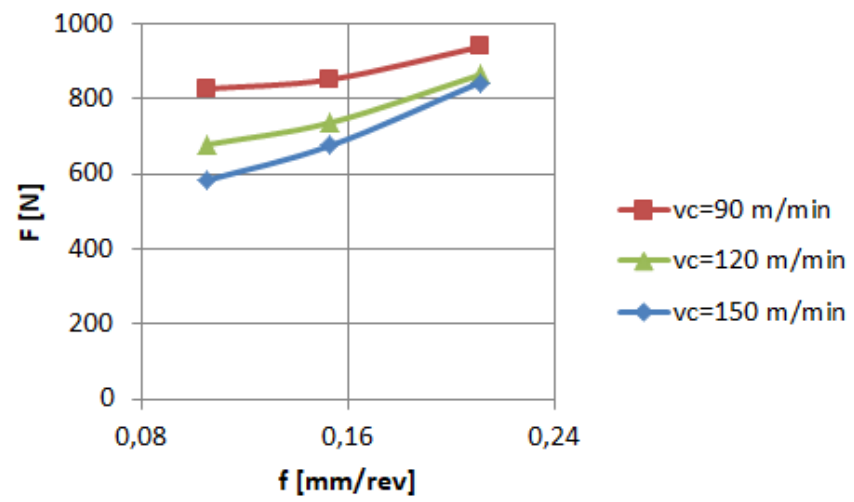

Fig. $5 \mathrm{c}$. The influence of the feed rate on the total cutting force, $a_{p}=1.5 \mathrm{~mm}$ 
Fig. $6 a, 6 b, 6 c$ present the influence of the depth of cut on the total cutting force value (at a constant cutting speed and feed rate).

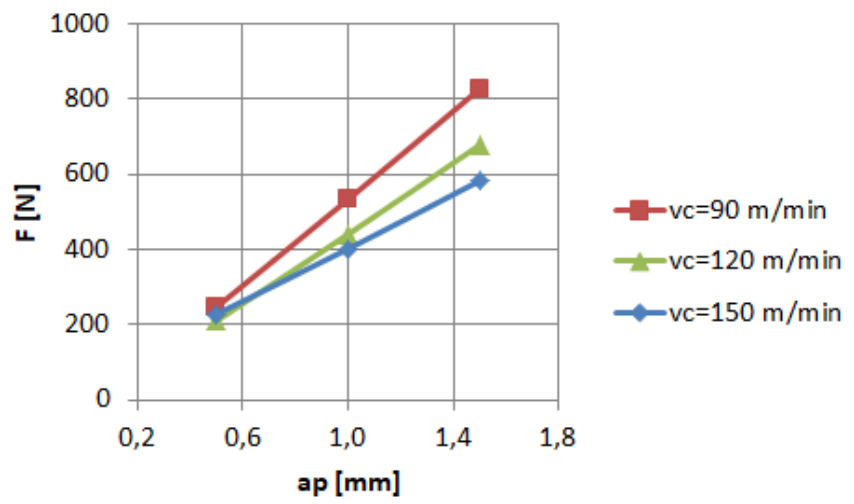

Fig. 6a. The influence of the depth of cut on the total cutting force, $f=0.105 \mathrm{~mm} / \mathrm{rev}$

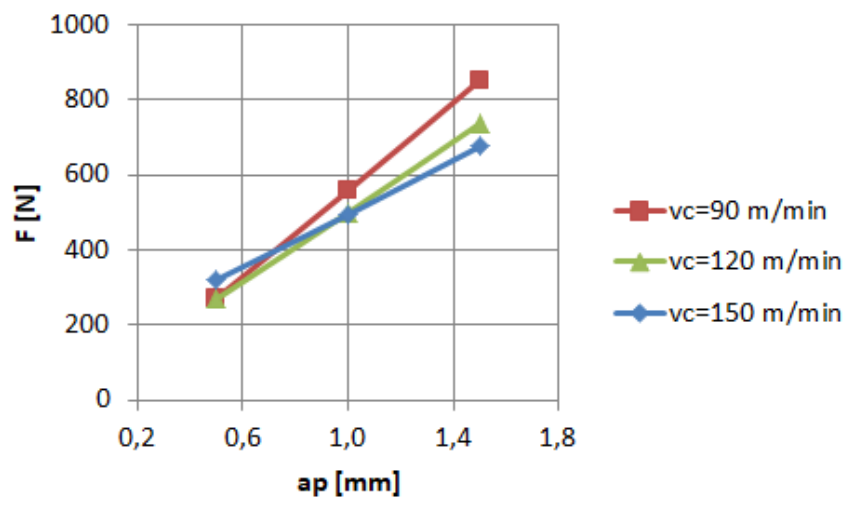

Fig. $6 \mathrm{~b}$. The influence of the depth of cut on the total cutting force, $f=0.153 \mathrm{~mm} / \mathrm{rev}$

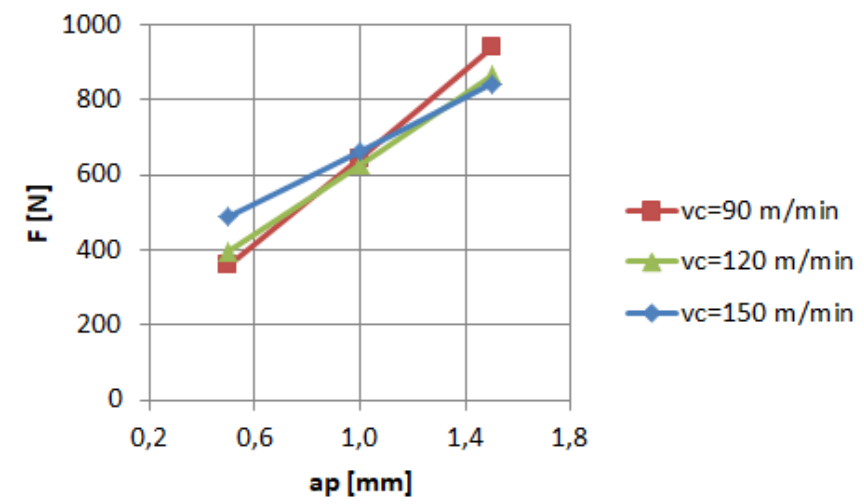

Fig. 6c. The influence of the depth of cut on the total cutting force, $f=0.211 \mathrm{~mm} / \mathrm{rev}$ 
Below are 3D graphs presenting the relationship between the cutting speed, feed rate and the total cutting force, for different depths of cut (Fig. 7) and the relationship between the cutting speed, depth of cut and the total cutting force for different feed rates (Fig. 8).

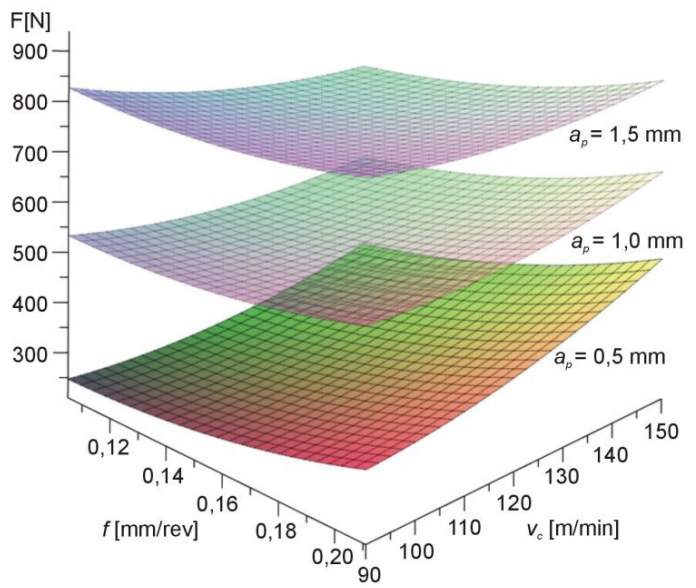

Fig. 7. The relationship between the cutting speed, feed rate and the total cutting force for different depths of cut

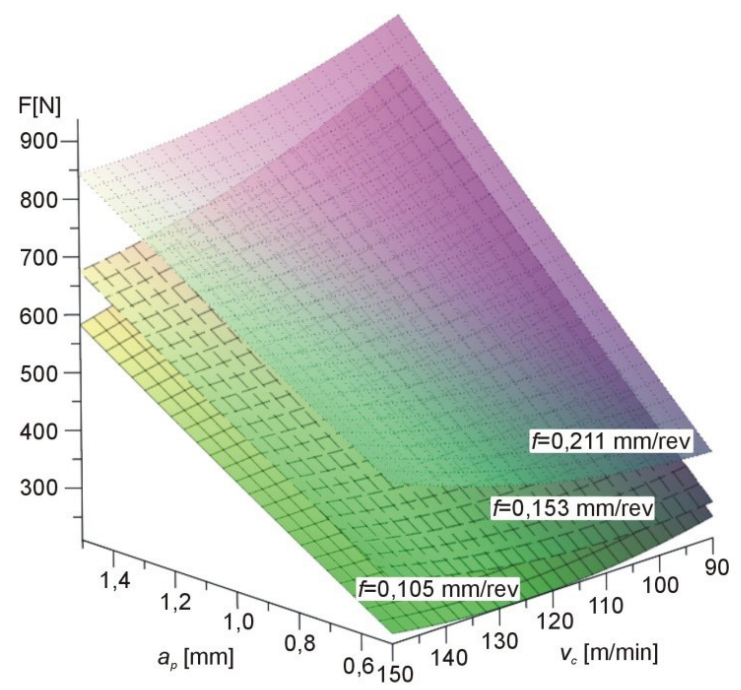

Fig. 8. The relationship between the cutting speed, depth of cut and the total cutting force for different feed rates 


\section{Conclusions}

The paper presents the results of parallel turning of the AMS5643 steel shaft using a non-coated S20 carbide insert. During the research, the main focus was concentrated on the values of components of the total cutting force $\left(F_{x}-\right.$ feed force, $F_{y}-$ radial force, $F_{z}-$ tangential force), which were recorded using a piezoelectric dynamometer. The research plan was made according to the Taguchi method, based on the L9 orthogonal table, which describes the research plan for three independent factors, with three different values of each. The independent factors in the presented tests were: $v_{c}$ - cutting speed, $f$ - feed, and $a_{p}-$ depth of cut. At each test, the highest value of force was recorded for the tangential component, followed by the feed, and the lowest for the radial thrust force.

Based on the ANOVA analysis of variances, the impact of individual cutting parameters on the value of the total cutting force was determined. It was found that the $a_{p}$, followed by $f$, has the greatest influence on the increase of the total cutting force value. A decrease in the total cutting force caused by the increase of $v_{c}$ in the considered range of variability is not significant. In future tests, the influence of the corner radius of the cutting insert on the cutting force value should be taken into account.

\section{References}

[1] Chomsamutr K., Jongprasithporn S., Optimization Parameters of tool life Model Using the Taguchi Approach and Response Surface Methodology, IJCSI International Journal of Computer Science Issues, 9, 1/3, 2012, 120-125.

[2] Ezugwu E.O., Bonney J., Yamane Y., An overview of the machinability of aeroengine alloys, Journal of Materials Processing Technology, 134, 2003, 233-253.

[3] Gawlik J., Zębala W., Ksztattowanie jakości wyrobów w obróbce precyzyjnej. Mechanik, 2005, 12/2011.

[4] Kruszczyński B., Stachurski W., Zgórniak P., Wplyw warunków obróbki podczas toczenia ostrzami typu Wiper na jakość powierzchni obrobionej i sity skrawania, Inżynieria Maszyn, 15/4, 2010, 7-20.

[5] Słodki, B., Zębala, W., Struzikiewicz, G., Correlation between cutting data selection and chip form in stainless steel turning, Machining Science and Technology, Vol. 19, Issue 2, 2015, 217-235.

[6] Ślusarczyk, Ł., Franczyk, E., Development and verification of a measuring stand for recording the physical phenomena during turning, Photonics Applications in Astronomy Communications Industry and High-Energy Physics Experiments Book Series: Proceedings of SPIE 10445, 104456G, 2017.

[7] Ślusarczyk, Ł., The construction of the milling process simulation models, Photonics Applications in Astronomy Communications Industry and High-Energy Physics Experiments Book Series: Proceedings of SPIE 10031, 100310C, 2016. 
[8] Zebala W., Modelowanie procesu toczenia materiatów trudnoskrawalnych, Czasopismo Techniczne, 5-M/2011.

[9] www.tachart.com/material/ams-5643 (access: 13.07.2018).

[10] PN/EN 10088-1:2005 Stale odporne na korozję. Część 1: Wykaz stali odpornych na korozję 